\title{
Rehabilitating the Ready-To-Wear Garment Industry in Nigeria: In Line with Related Skill, Operational and Environmental Strategies.
}

\author{
Emelue, F. (PhD) \\ Department of Fashion and Clothing Technology, \\ Delta State Polytechnic \\ Ogwashi-Uku, Delta State, Nigeria \\ E-mail: floxyemelue@yahoo.com
}

\begin{abstract}
Without doubt, the ready-to-wear garment industry is a multimillion dollar enterprise with the capacity of creating more than 300,000 (Three Hundred Thousand jobs) in Nigeria. Sadly, the non-development of this subsector of the fashion industry means that Nigeria continues to lose opportunities for foreign exchange earnings and job creation. Particularly disturbing is the apparent non-recognition of the economic benefits in the ready-to-wear garment industry which has led to the continued neglect by stakeholders, including the Nigerian government of the industry. This neglect has not only led to loss of scarce foreign exchange and contributed to the worsening of the unemployment rate in Nigeria but also put the sector into comatose. Given the potentials of a vibrant ready-to-wear garment industry in Nigeria, this paper explores the reasons for the stunted growth of the ready-to-wear garment industry. The paper goes further to contend that the solution to the problems of the ready-to-wear garment industry is multi-dimensional, and consist of adopting a holistic approach. The paper concludes by suggesting a three-prong strategy for reviving and rehabilitating the ready-to-wear garment industry in Nigeria.
\end{abstract}

Keywords: Fashion industry, VTE, skilled labour, ready-to-wear garment industry

Aims Research Journal Reference Format:

Emelue, F. (2018): Rehabilitating the Ready-To-Wear Garment Industry in Nigeria: In Line with Related Skill, Operational and Environmental Strategies.. Advances in Multidisciplinary \& Scientific Research Journal. Vol. 4. No.1, Pp 95-100.

\section{INTRODUCTION}

Garment is a piece of clothing used especially in contexts where one is talking about the manufacture or sale of cloths (Devaraja 2011). Garments are physical matter intended for a body. There are article of clothing used in covering the body. It can be used as an outer cover or outward appearance like dresses, suits, pants and so on. Garment can be produced at home or in the industry as ready -to- wear. Garment industry is a factory where materials of cloths are made for consumption. It is a factory where manufacturing of items of clothing are made or produced. The garment industry is involved in the production of ready-to-wear garment.

Ready to wear are garments that are mass produced opposite of custom made. However, custom made garment are items of clothing made according to individual purchaser specification. Ready- to- wear garment often abbreviated RTW, is the term for factory made clothing, sold in finished conditions. They are in standardized sizes as distinct from made to measure or bespoke. Made to measure or bespoke garments are tailored to a particular person's frame (Nathania, 2011). The productions of ready-to- wear garments involve the use of technologies and skills.

Technology is making use of knowledge of tools, technics, craft, systems or methods of organisation in order to solve a problem or serve some purpose. Technologies are available globally in the garment industry in the area of garment production, and it involves the use of skills.

Skill is an ability and capacity acquired through deliberate, systematic and sustained effort to smoothly and adaptively carryout complex activities or job function involving ideas. A skill is a type of work or activity which requires special training and knowledge. In order to rehabilitate the ready to wear garment industry, attention should be given to the area of skill, operation and environment. In the last five decades, as it concerns the fashion industry, the focus of Nigeria government and industry experts has been on the textile industry. The focus is perhaps premised on the success in terms of foreign exchange earnings and capacity for employment of the textile industry in the past. Operation strategy is a plan of action implemented by a firm that describes how they will employ their resources in the production of a product or service (Webfinance, 2013). By developing operational strategies, an industry can examine and implement effective and efficient systems for using resources, personnel and the process. The supervisors also see to the extent of work done in the stages of operations. 
While the operator work with different machines from designing to merchandizing to produce ready-to-wear garments for the mass market and this calls for some environmental concern. Environment according to Muhundhan (2013) is external conditions and surroundings of a work station. Environmental concern deals with the condition in the work place of the factory for improvement. It is therefore necessary to investigate how ready-to-wear garment production can be improved in terms of skill, operational and environmental strategies. Millions of naira worth of garment (readyto-wear) is imported into Nigeria yearly for ultimate usage and this depletes the foreign reserve, hence, federal government ban on imported garments. These has led to the establishment of garment industry which needs rehabilitation due to problems and challenges facing the industry. Given the foregoing, this paper presents a holistic view of the ready-to-wear garment industry in Nigeria with particular focus on the problems and challenges facing of the ready-to-wear garment industry and strategies for surmounting them.

\section{AN OVERVIEW OF THE READY-TO WEAR GARMENT INDUSTRY}

Of the various category of garments, the ready-to-wear garment is by far the most common. This is because of the relatively low prices of ready-to-wear garments. As a result of the low prices, the ready-to-wear garments have gained popularity. With increased popularity, and consequent demand for ready-to-wear garments, the industry has become a billion dollar industry. One noticeable trend in the ready-to-wear garment industry is the increasing role of developing nations in the production of ready-to wear garment. This is particularly so, because of the reversal of roles. Prior to this time, third world countries produced cotton and textile while industrial concentrated in the production of garments. The resultant effect of this reversal of roles brought about by economic necessities is the dominance of the more advance economy of the cotton and textile industry while garment making is outsourced to economically less developed countries. Following this reversal, several multilateral agreements and legislation designed to give effect to the new trend has come to effect, chief amongst which is the Cotonou Agreement, and The African Growth and Opportunity Act (AGOA).

With the huge positive impacts, this new paradigm shift has been embraced by these countries. In Bangladesh for example, the ready-to-wear industry plays a key role in employment generation and in the provision of income to the poor. Nearly four million workers are directly and more than twelve million inhabitants are indirectly associated with the industry. Over the past twenty five years, the number of manufacturing units has grown from 180 to over $4000{ }^{1}$ Similar impact has been recorded in Africa countries. In 2015, Kenya's total apparel exports reached USD 380 million. This figure was expected to grow by $5 \%$ in 2016 to reach USD 400 million. $^{2}$ In total contradiction to modern trends, the Nigeria fashion industry policy thrust is still primarily focused on cotton and textile production. This has left the ready-to -wear garment industry largely underdeveloped and incapable of exploiting the opportunities created in the ready-to-wear garment industry. Rather, Nigeria is reported to have $\$ 4$ billion in 2016 importing textiles and ready-made clothing. ${ }^{3}$ Currently, what is described as ready-to-wear garment firms in Nigeria are mere tailoring firms with the capacity to produce large quantity of simple garments primarily reliant on entrepreneurs in the South East Nigeria especially in Abia and Anambra. Characteristic of such ventures is low productivity in the quality and quantity of garments produced. It is therefore necessary to investigate strategies that will help improve the production of ready-to-wear garments.

\section{PROBLEMS AND CHALLENGES OF THE READY-TO-WEAR GARMENT INDUSTRY IN NIGERIA}

According to Njoku, the ready-to-wear garment industry is completely non-existent in the context of export capability, which is the ultimate objective of any ready-to-wear garment industry. She contends further that Nigeria does not participate in world production allocation, even after the opportunity offered by AGOA. ${ }^{4}$ This position appears to have support from the foregoing statement credited to Olusegun Awolowo, the Executive Director/Chief Executive Officer of Nigerian Export Promotion Council 'Nigeria successfully exported some apparels and textile goods. However, the last recent years have seen a downward trend in our textile and apparels export to the US. We are optimistic about the renewal captioned AGOA 2.0 and are positioning to exploit the opportunities that will come along with it. ${ }^{5}$

\footnotetext{
${ }^{1}$ Haider, M.A (2007), "Competitiveness of the Bangladesh Ready-made Garment Industry in Major International Markets", Asia-Pacific Trade and Investment Review, Vol. 3, No.1.

${ }^{2}$ http://www.eleksie.co.ke/cotton-textile-and-apparel/

${ }^{3} \mathrm{http}: / /$ www.businessdayonline.com/nigeria-spends-over-4-billion-annually-importing-textiles-ready-made-clothing-ntma/

${ }^{4}$ Marketability Of Made In Nigeria Textile Materials By Uju Angela Anyigbo Njoku

http://www.stclements.edu/grad/gradnjok.pdf.

${ }^{5}$ http://nepc.gov.ng/wp-content/uploads/2017/07/Brochure-made-in-Nigeria.pdf.
} 
This state of affairs is surprising as vision 2020 puts garment production and export to ECOWAS countries as high priority. ${ }^{6}$ Apart from the inability to take advantage of export opportunity provided by the AGOA, Nigeria ready-towear garment industry has been unable to maximize the potential provided by the country's large population. Domestically, the ready-to-wear garment industry is at its infancy. Most ready-to-wear garment outfits in Nigeria are mainly occupied with sewing uniforms and promotional garments at a relatively low scale. Several reasons have been put forward to explain the failure of Nigeria to take advantage of the opportunities in the ready-to-wear garment industry both domestically and internationally. Regardless of the reasons adduced, the problems can be subsumed under three categories, namely skill, operational and environmental related problems. Most prominent of the several problems is the lack of skilled labour. This shortage of skilled labour has been traced to the failure of Nigeria educational system to effectively transfer usable skills. Closely related is poor craftsmanship of the available labour. The resultant effect of poor craftsman is poor quality of the garments produced. The quality of ready-to-wear garments production in Nigeria with regard to design, fabric choice, pattern, cutting, assembling, finishing, packaging and merchandizing are below those produced outside the shores of this country. The quality of fabric, design selection are poor, loose fitting, poor finishing and poor detail treatment in the following areas: pocket, neck line, sleeve, waist line, hem, closures and decorative detail which give room to more alterations and poor fit. The quality and durability of garments produced cannot be compared with the imported ones. ${ }^{7}$

The second major challenge facing the ready-to-wear garment industry in Nigeria, is the problem of optimal utilisation of available resources. There is no doubt that Nigeria is endowed in terms of resources as well as a large population, all which are pre-requisite for growing a vibrant ready-to-wear garment industry capable of meeting domestic demands of ready-to-wear garments. Unfortunately, the inability to deploy resources to meet predetermine objectives has resulted in the failure of successive government to successfully implement developmental plans and policy.Thirdly, the social cum political environment has hampered the growth of ready-to-wear garment industry in Nigeria. These social cum political environment include infrastructural decay, the problem of power, policy inconsistency etc. Repeatedly, these problems, particularly the problem of power supply is generally blamed for the near demise of the textile industry in Nigeria.

\section{STRATEGIES FOR REHABILITATING THE READY-TO WEAR GARMENT INDUSTRY IN NIGERIA}

Developing and proffering solutions to systemic and hydra-headed problems like the one associated with the readyto-wear industry in Nigeria requires a deliberate and well-thought out strategy. Strategy is a novel or skilful approach to problem or finding solution to problem with a view to achieving a stated goal (Ozioko, 2007). ${ }^{8}$ It is therefore essential in order to achieve the desired goal to identify strategies that addresses all aspects of the problems technologies, skills, operational and environmental to improve the productivity in quantity and quality of ready-to-wear garments. The appropriate strategy in this context are skill, operational and environmental related strategies.

\subsection{Skill-Related Strategy}

Skills acquisition by labour is a fundamental requirement to any strategy productive endeavour. In relation to the ready-to-wear garment industry, there is an urgent need to transform and refocus the TVE sector of Nigeria educational system. This is especially important given the failure of the TVE sector of Nigeria education to solve the perennial problem of lack of skilled labour across all productive sector of the Nigerian economy. In order to transform and refocus the TVE sector as it pertains to the fashion industry in general, and specifically the ready-to-wear garment industry, certain core measures must be undertaken. The first is to re-focus the learning objective of fashion departments from dressmaking to garment manufacturing. The former trains students to cater for single customers, while the later trains students to cater for a larger market. One of the ways of achieving this objective is for all fashion departments to set up commercially viable production units engaged in mass production of garments. With this, the student will witness first-hand the economic viability and potential of garment production. The second approach, which is closely related to the first is for all fashion departments to strictly adopt competence based education and training to strengthen practical skills. This will result in seamless transfer of skilled labour from school to workplace, thereby reducing the time and cost of retraining labour. Remarkably, the Students Industrial Work Experience Scheme (SIWES) which was set up with the primary objective of exposing and preparing students of universities and other tertiary institutions for the Industrial Work situation after graduation has failed to achieve its objective.

\footnotetext{
${ }^{6}$ http://www.nigerianstat.gov.ng/pdfuploads/Abridged_Version_of_Nigeria\%20Vision\%202020.pdf.

1. 7 Emelue, F.(2015) Strategies for Improving the Production of Ready-to Wear Garments in Clothing Industries in South East Nigeria (Un

2. There are no sources in the current document.published doctoral dissertation) available from: www. Unn.edu.ng/internals/repository/show/14760

${ }^{8}$ Ozioko, N., (2007). Mobile-Friendly-Fashion. Thenet.ng>tag>nwachukwu-ozioko.

Pearson education
} 


\subsection{Operational Strategy}

Operational strategy is a plan of action implemented by an organisation of the deployment of resources to achieve a particular productive objective. ${ }^{9}$ An operational strategy, which is a term often used in the business environment, is a prerequisite for achieving corporate goals. According to Richards-Gustafson, (2014), operational strategy is the total pattern of decisions which shape the long-term capabilities of any type of operations and their contribution to the overall strategy. ${ }^{10}$ Simply put, operational strategy is the development of a long-term plan for using the major resources of the industry for a high degree of compatibility between these resources and the industry's long term corporate strategy. In any production industry, operations strategy addresses very broad questions about how these major resources should be configured to achieve the desired corporate objectives (Welters, 2006). ${ }^{11}$ According to Welters, some of the major long-term issues addressed in operations strategy include: how large do we make our facilities, what type of process do we install to make the products or provide services, what will our supply chain look like, what will be the nature of our workforce and how do we ensure quality. There is no doubt that operational strategy is essential to the successful implementation of production decisions in firms as well as policies in government. Nigeria notoriety for policy somersault, incapacity to engage in long-term planning and implementation, inefficiency in allocation of resources towards achieving stated objectives underscores the need for an operational strategy. More importantly, there is need for synergy in the operational strategy adopted by government and ready-towear garment firms.

\subsection{Environmental Strategy}

Environmental strategy in this context refers to the business environment in which a business operates as against the alternative reference to environmental protection strategies of a production firm. Environment strategy therefore refers to factors in the business environment which either serves as incentive or disincentive to businesses. It encompasses a range of factors such as infrastructure, power, legislation and taxation Etc. Environmental strategy is so important that is constitutes the major criteria for measuring the "ease of doing business", a World Bank Group initiative for measuring the incentives or otherwise of doing business in a particular country. Currently, Nigeria ranks 145 th position out of 190 countries in the Ease of Doing Business index for $2018 .^{12}$ Specific criteria for rating countries include ranking on 10 key indicators: starting a business, dealing with construction permits, registering property, getting credit, protecting investors, paying taxes, trading across borders, enforcing contracts, resolving insolvency and getting electricity. In adopting an environmental related strategy to revive and rehabilitate the readyto-wear garment industry in Nigeria, it is of utmost importance that factors such as power supply, poor infrastructure are given utmost priority in order to create an enabling business environment capable of not only attracting new businesses but also attracting new businesses.

\section{CONCLUSION}

The potential of the ready-to-wear garment industry is almost limitless in terms of earnings as well as in the creation of employment for Nigerians. This is excluding the ripple effect of a vibrant ready-to-wear garment industry on other sectors such as haulage, shipping, banking, insurance as well as other facets of the Nigeria economy. As has been observed, other countries in similar developmental stage as Nigeria, have benefitted immensely from the operations of the ready-to-wear garment industry in their respective countries. The success of these countries demonstrates the ease of replicating the results in Nigeria. All that is required to rehabilitate the ready-to-wear garment industry is for the government, private investors to recognise the opportunism that lies in the ready-to-wear garment industry.

\section{REFERENCES}

1. Sub-Saharan African Textile and Apparel Inputs: Potential for competitive production: A report of United States International Trade Commission. Investigation No 332-502 USTC Publication 4078, May 2009.

2. Devaraja, T. S. (2011) Indian Textile and Garment Industry, Indian University of MiYsore Press.

3. Nathania, Z. (2011) Custom Tailors Enjoying a Boom. Retrieved from www.wsj.com/articles/SB.on 3rd of August 2017

4. Webfinance (2013) Operational Strategy Retrieved $11^{\text {th }}$ March 2014 from http.//www.businessdictionary.com/httm.

5. Muhundhan. M. (2013) Improved Work Station Design for Improved Productivity. International Journal of Scientific Engineering and Technology, 2(3), 225-227.

\footnotetext{
${ }^{9}$ (WebFinance, 2013).

${ }^{10}$ Richards-Gustafson, F., (2014). 5 Core Operational Strategies. Texas: Houston Chronicle.

${ }^{11}$ Welters, D., (2006). Effectiveness and Efficiency: The Role of Demand Chain Management. The International Journal of Logistics Management, 17(1), 75-94.

Read more at: https://www.vanguardngr.com/2017/10/nigeria-moves-24-points-world-bank-ease-business/
} 
Advances Mu Muttidisciplinary

APs \& Scientific Research

Vol. 4 No. 1, March 2018 
Advances Mu Muttidisciplinary

APs \& Scientific Research

Vol. 4 No. 1, March 2018 